\title{
anemon
}

Muş Alparslan Üniversitesi Sosyal Bilimler Dergisi

Journal of Social Sciences of Muş Alparslan University

Yı//Year: 2017 • Cilt/Volume: 5 • Sayı/Number: 1

ISSN: 2147-7655 • e-ISSN: 2149-4622

ÖZGÜN ARAŞTIRMA • ORIGINAL ARTICLE

\section{Türkiye’de İdari Reform Çalışmalarının Tarihsel Perspektif Açısından Değerlendirilmesi}

\author{
Yasemin MAMUR IŞIKÇI I,a \\ ${ }^{1}$ Yrd. Doç. Dr., Giresun Üniversitesi, İ̈BF, Siyaset Bilimi ve Kamu Yönetimi Bölümü- Giresun / Türkiye \\ Başvuru tarihi: 14 Kasım 2016 \\ Düzeltme tarihi: 19 Ocak 2017 \\ Kabul tarihi: 30 Ocak 2017
}

Öz

Küreselleşme ile birlikte gittikçe yaygınlaşan neo-liberal politikalar devletin rolünde de bir değişimi zorunlu kılmış, 1930'lu yıllarda meşruiyet kazanmış olan müdahaleci devlet anlayışının yerini, 1980'li yıllardan sonra düzenleyici devlet anlayışı almıştır. Bu çalışmanın amacı; yönetimi alanındaki idari reformları devletin rolündeki değişim süreci ile birlikte tarihsel olarak analiz etmektir. Söz konusu analiz, uzman raporları, kalkınma planları, Avrupa Birliği İlerleme Raporları ve uygulama üzerinden yapılmıştır.

Türkiye'de yapılan idari reform çalışmaları tarihsel olarak dönemlere ayrıldıktan sonra, 2000 yılı sonrası yeniden yapılanma çalışmaları ayrıca irdelenmiş ve son aşamada da bu çalışmaların başarısı ve geleceği hakkında bir değerlendirme yapılmıştır. Çalışma sonunda Türkiye'de cumhuriyet tarihinde yapılan idari düzenlemelerin 1980'li yıllara kadar dar kapsamlı ve daha çok örgütsel sorunları kapsayan kapalı bir anlayış hakimken, 1980'li yıllardan sonra daha kapsayıcı ve köklü değişimleri içerdiği belirlenmiştir.

\section{Anahtar Kelimeler}

İdari Reform, Kamu Yönetimi, Küreselleşme, Türkiye

\footnotetext{
a Sorumlu Yazar/Correspoding Author: Giresun Üniversitesi, İktisat ve İdari Bilimler Fakültesi, Siyaset Bilimi ve Kamu Yönetimi Bölümü, 28100, Giresun/Türkiye.

e-posta: mamurysm@gmail.com 


\title{
Evaluation of Administrative Reforms with Regard to Historical Perspective in Turkey
}

\begin{abstract}
Neoliberal policies, which were becoming more widespread with globalization, necessitated a change in the role of the state, and therefore the notion of interventionist state which was legitimated in the 1930's was replaced by the regulatory state in the 1980's. The aim of this study is to analyze the administrative reforms in the public administration area historically as regards the process of change in the role of the state. The analysis was based on expert reports, development plans and implementation. Although it is directly related to the research, European Union Progress Reports were excluded from the scope of this study.

After the administrative reforms in Turkey were separated historically, those made in the post-2000 era have been thoroughly examined, and an evaluation of the success and the future of these efforts has been provided. At the end of the study, it was determined that administrative reforms made in the Republican period in Turkey followed a narrow-scoped and isolated path that focused more on organizational issues until the 1980's, whereas more inclusive and radical changes were implemented after the 1980's.
\end{abstract}

Keywords

Administrative Reform, Public Administration, Globalization, Turkey

\section{GİRIŞ}

Küreselleşme süreci ile birlikte etkisi ve yaygınlığı artan neoliberal politikalar devletin rolünde ve yapısında bir değişime yol açmıştır. Küreselleşme ile birlikte, daha önce kapitalist sistemin içine girdiği darboğazda, müdahaleci, yeniden dağıtımcı ve yön verici bir görev verilen devlet, yaşanan krizin sorumlusu olarak görülmüş ve bu nedenle devletin küçültülmesi gerektiğini savunan liberal söylemler küresel olarak yaygınlık kazanmıştır. $\mathrm{Bu}$ söylemlerin işaret ettikleri taleplerin uygulamaya konulmasıyla ülkelerin siyasal ve yönetsel yapılarında büyük dönüşümler yaşanmaya başlanmıştır. Söz konusu olan bu dönüşümler, idari reform girişimleri ile gerçekleştirilmektedir.

$\mathrm{Bu}$ gelişmenin etkileri Türk kamu yönetiminde de görülmektedir. Kamu hizmetlerinde neoliberal yeniden yapılandırma süreçleri 1980'lerden itibaren Türkiye'de etkisini göstermeye başlamış, Türk Kamu Yönetiminde bu dönüşüme yönelik ciddi adımlar 2000'li yılların başından itibaren atılmaya başlanmıştır. Bu çizgide dönüştürmeye yönelik en ciddi adımlar da 2000'li yılların başından itibaren atılmaya başlanmıştır.

$\mathrm{Bu}$ çalışmanın amacı kamu yönetimi alanındaki idari reformları devletin rolündeki değişim süreci ile birlikte tarihsel olarak analiz etmektir. Söz konusu analiz, uzman raporları, kalkınma planları, Avrupa Birliği İlerleme Raporları ve uygulama üzerinden yapılmıştır. 
Çalışmada bundan sonraki kısımda Türkiye'de yapılan idari reform çalışmaları tarihsel olarak dönemlere ayrıldıktan sonra 2000 yılı sonrası yeniden yapılanma çalışmaları irdelenecek ve son aşamada da bu çalışmaların başarısı ve geleceği hakkında bir değerlendirme yapılacaktır.

Literatür taramasında çalışma problemi ile doğrudan ilgili birkaç eser dikkati çekmiştir. Bunlardan bazılarını şu şekilde sıralamak mümkündür;

Sürgit (1972) çalışmasında Türkiye'de idari reform girişimlerini tarihsel olarak ortaya koymuştur. Berkman, (1982) araştırmasında planlı dönemde idari reform anlayışı ve uygulamalarını tahlil etmiştir. Ergun (1991) çalışmasında öncülüğünü ettiği KAYA projesinin yönetimin yeniden yapılandırılmasına katkısını açıklamıştır. Şaylan (1995) çalışmasında Türk kamu yönetimindeki reform çabalarını küreselleşme süreci ile birlikte devletin rolünde meydana gelen değişimlerle birlikte açıklamıştır. Güler' de (1996) çalışmasında son dönem devletin rolündeki değişimleri ve neoliberal politikaların Türk kamu yönetimindeki yansımalarını incelemiştir Tutum (1994) çalışmasında Türk kamu yönetimindeki reform çabalarını tarihsel olarak analiz etmiştir. Yayman (2008), araştırmasında Türkiye'nin idari reform hareketlerinin politiğini irdelerken özelde idari reform hareketlerinin gelişimi, ulaşılan sonuçlar, yönetim geleneğinin dönüşümü ve reform çalışmalarının arka planını analiz etmiştir. Yayman, (2005) başka bir araştırmasında Türkiye'de reform projelerine esas olan toplumsal, siyasal ve uluslararası koşulları ve idari reformların politik boyutunu incelemiştir. Çiner (2010) araştırmasında Türk kamu yönetimindeki idari reform girişimlerini yerelleşme ve bölgeselleşme unsurları açısından incelemiştir. Karaer (2011) çalışmasında birinci, ikinci, üçüncü ve dördünce beş yıllık kalkınma planları özelinde Türk Kamu Yönetiminde reform girişimlerinin tarihsel gelişimini incelemiş̧ir. Benzer bir çalışmayı Övgün (2013) mevcut dokuz kalkınma planı üzerinde gerçekleştirmiştir. Lamba (2014) ise, özellikle son dönem idari reform çalışmalarını uygulamalar üzerinden incelemiştir.

\section{2. İDARİ REFORMUN TANIMI}

Reform kavramı, Avrupa'da 16. yüzyılda Hıristiyanlık dininde ortaya çıkan yeni yorum ve düzenlemeleri, birey üzerindeki kilise vesayetinin kaldırılmasını ifade etmek üzere kullanılmıştır. $\mathrm{Bu}$ anlamda reform hareketleri öncelikle Almanya'da başlayarak sonrasında da Fransa, İngiltere ve diğer Avrupa ülkelerine yayılmıştır (Kılıç, 2006: 39).

Yönetimde reform ya da başka bir deyişle idari reform kavramı ise kamu sektöründeki yapı, süreç ve kalitenin geliştirilmesi amacıyla gerçekleştirilen bilinçli ve sistemli değişiklikleri ifade etmek üzere kullanılmıştır (Gow, 2012).

$\mathrm{Bu}$ alanda kavram ve kapsam belirsizliği olduğunu da belirtmek gerekir. İdari reform kavramı yerine, "1slahat, rasyonalizasyon, reorganizasyon, modernizasyon, reform ve son zamanlarda da yeniden yapılanma" kavramlarının kullanıldığı görülmektedir. Coşkun ve Nohutçu (2005) belirttikleri üzere; kamu yönetiminde köklü bir değişim ihtiyacından sürekli bahsediliyor olması, idari yapıların eskimiş geleneksel yapılarından arındırılması gerektiği düşüncesi "idari reform" kavramını daha çok ön plana çıkarmıştır. Bununla birlikte; idari reform kavramı daha çok dar kapsamlı uygulamaları işaret etmek için kullanılırken son zamanlarda geniş kapsamlı ve köklü değişiklikleri ifade etmek için 
"yeniden yapılanma" kavramı tercih edilmeye başlanmıştır. Yine de yeniden yapılanma kavramının idari reform kavramına paralel şekilde kullanılmaya devam ettiğini hatırlatmak gerekir.

Kamu Yönetimi Sözlüğü’nde de “idari 1slahat”, “yönetim reformu”, “idarenin yeniden düzenlenmesi" sözcüklerinin "idari reform" ile eş anlamlı olduğu ifade edilmekte ve idari reform; "kamu yönetimini daha etkili ve daha verimli kılmak, iyileştirmek amacıyla girişilen yeniden düzenleme çabaları ve bunun sonucunda gerçekleştirilen yenilikler" şeklinde ifade edilmektedir (Bozkurt vd., 1998: 104).

Berkman'da (1982) idari reform kavramını “bir yönetim sisteminin amaçlarına yönelik olarak işlevlerini daha hızlı, nitelikli, verimli ve etkili bir şekilde yapacak düzeye çıkarmak üzere örgütsel yapı ve süreçte, idari yöntem ve tekniklerde veya personel unsurunda yapılan bilinçli değiştirme, yeniden düzenleme girişimleri” olarak tanımlamaktadır. Ancak, bu tanım, reform çalışmalarının, bir unsuru oldukları siyasi sistemi etkileme ya da bu sistemden etkilenme durumunu dişlayan bir tanımdır. $\mathrm{Bu}$ anlamda Tutum' un yapmış olduğu tanım idari reform kavramının kapsayıcı yönünü daha açık bir şekilde ortaya koymaktadır. Tutum' un (1994) tanımına göre idari reform; yönetim sisteminin yapısında, hizmet tercihlerinde, personel rejiminde, iş görme zihniyeti ve yöntemlerinde, karar verme sürecinde, siyasal sistemle olan ilişkilerinde ve sistemi harekete geçiren dürtülerde köklü değişiklikler demektir. Böylesi bir tanım bizce idari reform kavramının niteliğini daha çok gözler önüne sermektedir.

\section{3. İDARİ REFORM YAPMA GEREĞİ}

Literatürde kamu yönetiminde reform yapılmasının pek çok nedeni sayılmaktadır. Bunlar genellikle, kamu yönetiminin idari kuruluşların teknolojik, sosyolojik, ekonomik ve çevresel değişmelere ayak uydurmasını sağlamak, zamanla değişen ihtiyaç ve talepleri karşılayabilmesi saptamalarının etrafında yoğunlaşmaktadır.

Ancak bizce, bir ülkede ya da yönetimde yeniden yapılanma yoluna gidilmesi gereğini doğuran en büyük etken, dünya çapında yaşanan iktisadi, sosyal ve toplumsal gelişmeler sonucu devletin rolünde yaşanan değişimler ve değişimlere kamu yönetiminin uydurulmasıdır. Denilebilir ki, devlete biçilen role uygun olarak öncelikle reformun amaçları belirlenmekte ardından da reformun nedenleri sıralanmaktadır. Kısacası bir bakıma reformun amacı, aynı zamanda reformun nedeni olmaktadır. Reformun amacı hemen her zaman da devlete verilen rolün en iyi şekilde gerçekleştirilmesini sağlamaktır. Devletin rolündeki değişimlerin kamu yönetiminde yapılan idari reformları nasıl etkilediği konusu aşağıdaki bölümde açıklanacaktır;

\section{KAMU YÖNETIMINDE PARADIGMA DEĞISSIMI VE REFORM HAREKETLERİ}

Adam Smith ve John Locke’ un öncülüğünde gelişen liberalizm özgürlükleri korumak adına, devletin, güvenlik, adalet ve savunma hizmetleri dışında hiçbir görev üstlenmemesini ve iktisadi hayatın dışında kalmasını savunmuştur. Bu nedenle devlet, liberal düşüncenin ortaya çıktığg 1900'lü yılların başlarında kendine yüklenen bu rol 
çerçevesinde, ekonomiye, bireye ve topluma oldukça mesafeli durmuştur. Ancak 1920'li yılların sonlarından itibaren liberalizmin üzerinde yükseldiği kapitalist sistem talep yetersizliği nedeni ile sıkıntı çekmeye başlamış ve nihayet 1929 yılında ekonomik buhran olarak adlandırılan büyük bir buhran içine girmiştir. Bu dönemde 1. Dünya Savaşı'nın neden olduğu yoksulluk ve kaynakların yetersizliği serbest piyasa ekonomisinin uygulanmasını da zora sokmuştur. İşte bu ortamda, devletin piyasaya karışmaması sorgulanmış ve devletin piyasaya müdahale etmesi gerektiğini savunan Keynesyen politikalar uygulamaya konulmuştur.

Sonra ki süreçte, İkinci Dünya Savaş'ının neden olduğu yıkımın giderilmesi için altyapı, ulaşım ve sosyal politika alanlarında da devlet çok fazla sorumluluk üstlenmek durumunda kalmıştır. Böylelikle 1960’lı yıllarda, kamu yönetimi kendinden beklenenleri yerine getirebilmek için birçok alanda faaliyet göstermek durumunda kalmıştır

Talep yetersizliği nedeni ile girdiği 1929 Büyük Bunalımını devletçi uygulamalarla atlatan kapitalist sistem 1970'lerden itibaren, artan görevleri ve düşen kar oranları nedeni ile 1973 yılında yeni bir krize girmiştir. Kapitalist sistemin yaşadığı çıkmaz, devletin ekonomik ve sosyal yaşamdaki görevlerini azaltmayı amaçlayan neoliberal politikaları ortaya çıkarmıştır. 1980 sonrası dönemde küreselleşme süreci ile yaygınlık kazanan neoliberal politikalar, kamu harcamalarının kısılarak devletin ekonomiye müdahalesinin en aza indirilmesini amaçlamıştır. "Keynesyen ekonomiye bir karşı duruşu ifade etmesinden dolayı bu yaklaşımlar, ekonomide devlet müdahalesi yerine serbestliği önermekteydi. Dolayısıyla bu yeni anlayışla (Keynesyen politikalara dayanan) Refah Devleti anlayışının sürdürülmesi imkânsızlaşmıştır ve 'küçülmeci devlet' yaklaşımına geçilmesi zorunluluğu doğmuştur” (Çiftçi ve Çürük, 2011: 31).

$\mathrm{Bu}$ şekilde ortaya çıkan yeni paradigmaya göre, devletin küçültülmesi yolu ile faaliyet alanı sınırlandırılmalı, devlet mümkün olduğunca kamu hizmeti sunmamalı ancak kamu hizmeti niteliği olan her alanda kuralları koymalı, politikaları belirlemeli ve alanda faaliyet gösteren aktörler arasında hakem olmalı, kamu hizmeti sunarken de verimlilik, etkililik ve etkinlik denetimi yapmalıdır. $\mathrm{Bu}$ düzenleyici anlayışın kamu yönetimine yansıması ise, özelleştirme, yerelleştirme, yönetimde işletme değer ve tekniklerinin kullanılması şeklinde olmuştur. İdari reformlarla yapılmaya çalışılan ise bu bağlamda, kamu yönetimini, devleti, kendinden beklenen görevi yerine getirebilmek üzere etkin kılmaktır. Bunu gerçekleştirmek üzere devletin rolü değiştikçe, kamu yönetimi de idari reformlar aracılı̆̆ 1 ile değiştirilecektir.

Yukarıda sözünü ettiğimiz gelişmeler sonucu 1980'li yılların başından itibaren devletin rolünde meydana gelen değişmeler, kamu yönetimi alanında da köklü değişikliklere gidilmesini zorunlu kılmıştır. Bu dönemden önce her şeye ve her alana müdahale eden ve bu nedenle şişen devleti küçültme bu dönemden sonra yapılan idari reformların ana amacı olmuştur. Ancak bu aşamaya nasıl gelindiğini görebilmek için 1980 öncesi idari reformların niteliğini öncelikle ortaya koymak gerekir.

Bundan sonra ki kısımda Türkiye'de yapılan idari reform çalışmaları tarihsel olarak 1980 öncesi ve 1980 sonrası olarak dönemlere ayrıldıktan sonra, 2000 yılı sonrası yeniden yapılanma çalışmaları irdelenecek ve son aşamada da bu çalışmaların başarısı ve geleceği hakkında bir değerlendirme yapılacaktır. 


\section{1980 ÖNCESİ DÖNEMDE İDARİ REFORM ÇALIŞMALARI}

Cumhuriyet döneminde idari reformlar ilk defa kapsamlı olarak yabancı uzmanların hazırladıkları raporlarla başlamıştır. 1962 yılında DPT ${ }^{1}$, TODAIE ${ }^{2}$ ve Devlet Personel Dairesi'nin ${ }^{3}$ kurulmasından sonra da bu kurumların hazırladıkları raporlar ve kalkınma planları reform sürecinde ön plana çıkmıştır. Bu dönemdeki reform çalışmalarını uzman raporları, kalkınma planları ve uygulama üzerinden değerlendirmek yerinde olacaktır.

\subsection{Uzman Raporlarında İdari Reform Çalışmaları}

Cumhuriyet döneminde idari reform çalışmalarına kaynak oluşturmak üzere idari yapıdaki sorunları tespit etmek ve öneriler geliştirmek üzere birçok inceleme yapılmış ve bu incelemelerin sonuçları da raporlar halinde yayınlanmıştır. Bu çalışmaların yapılmasında yabancı uzmanlardan da yararlanılmıştır. Bu raporları aşağıda şu şekilde sıralamak mümkündür;

Dorr Raporu: Goldthwaite H. Dorr tarafindan 1933'te yapılan çalışma da kalkınma için gerekli, hamlelerin devlet eliyle yapılması, özel sektörün desteklenmesi, kaliteli yöneticilerin yetiştirilmesi önerilmiştir. Metinde birçok sektörle ilgili tavsiyelerde bulunulmuş, özellikle sanayi, tarım, altyapı, ticaret, devlet maliyesi, ulaşım ve maden alanlarına yönelik incelemeler yapılmıştır. (Yayman, 2008: 96-98)

Thornburg Raporu: Türkiye'nin II. Dünya savaşı sonrasında ABD tarafindan Marshall Planı içerisine alınması sonucu Amerikalı bir ekip tarafından 1949 yılında yapılan bir çalışmadır. (Kara, 2006: 153) Raporda, devlet eliyle yapılan iktisadi çabalar eleştirilmiş ve sanayileşme faaliyetlerinde liberal politikaların desteklenmesi önerilmiştir (Yayman, 2008: 135).

Neumark Raporu: İstanbul Üniversitesi İktisat Fakültesi eski Profesörü olan Neumark, başbakanlığın isteği üzerine 1949 yılında 'Devlet Daire ve Müesseselerinde Rasyonel Çalışma Esasları Hakkında Rapor' adlı bir rapor hazırlamıştır. Neumark raporunda, idare ile ilgili sorunlar, bakanlık sayısının ve onlara bağlı birimlerin sayıca fazla olması, katı merkeziyetçilik, bürokrasi ve kuralcılık, memur sorunları, liyakat unsuruna önem verilmemesi, denetimden kaynaklanan sıkıntılar, halkın yönetime katılamaması ve kamusal işler konusunda halkın bilgilendirilmemesi olarak sıralanmıştır. Bu sorunlara yönelik öneriler ise, şeffaflık, bakanlık sayısının azaltılması, örgüt yapılarının sadeleştirilmesi, liyakat ve denetim unsurlarına önem verilmesi, memur sayısının azaltılması, yönetimde şeffaflığı sağlamak üzere halkın kamusal sorunlar ve çözümleri konusunda bilgilendirilmesini sağlamak için enfarmosyon dairelerinin açılması, memurların ve müfettişlerin niteliklerinin artırılması, kural ve kanunların sadeleştirilmesi (Yayman, 2008: 135) olarak sıralanmıştır.

Barker Raporu: Dünya Bankası adına, James Barker ve çalışma ekibi tarafından Türkiye'nin ekonomik kalkınmasını gerçekleştirecek yönetsel ve mali yapı hakkında öneriler sunmak üzere kaleme alınmış ve 1951'de tamamlanmış olan rapor, Neumark raporunda olduğu gibi personel sorunları, aşırı merkeziyetçilik, katı kuralcılık, liyakata önem verilmemesi ve bürokrasi sorunlarını sıralamaktadır. Raporda bu sorunlara yönelik olarak da merkeziyetçiliğin azaltılması için, yerel yönetimlerin güçlendirilmesi ve yerel 
yönetimlere daha fazla kaynak aktarılması, memur sorunlarına yönelik olarak da işe almalarda liyakata önem verilmesi, hizmet içi eğitimler yolu ile memurların niteliğinin artırılması, memurların dengeli dağılımını sağlamak üzere merkezi bir personel dairesinin kurulmasını önermektedir. Ayrıca kamu yönetimi kürsülerinin kurulması gerektiği bu raporla ifade edilmiştir

Martin ve Cush Raporu: 1951 yılında James V. Martin ve Frans C.E. Cush tarafindan Maliye Bakanlığı için hazırlanan raporda, Maliye Bakanlığı'nın örgütlenme, çalışma metotları ve personel sorunları ele alınmış, bir önceki saptamalar Maliye Bakanlığı özelinde tekrarlanmıştır.

Leimgruber Raporu: Hükümetin isteği üzerine, 1952 yılında İsviçreli Profesör Leimgruber, tarafindan sunulan raporda personel sorunları, personelin sinıflandırılması çalışma saatleri, maaşlar, personelin hukuksal statüleri, ücret rejimi, personel kadrolarındaki şişkinlik, vb. konulara değinilmiş̧ir. (Işı1, 1965:8)

Görüldüğg̈ gibi, 1960’lara kadar, yani planlı dönem başlamadan önceki dönemde idareyi geliştirme adına yapılan çalışmalar yabancı kaynaklı olmuştur. 1960 yılından sonra bu çalışmalar hem yerli uzmanlarca hem de daha kapsamlı ve bütünlükçü bir şekilde yapılmıştır. Bu olumlu sonucun doğmasında iki gelişmenin büyük etkisi olmuştur. Bunlardan biri, Birleşmiş Milletler ile hükümet arasında imzalanan ve 6319 Sayılı Kanun'la onaylanan Teknik Yardım Ek Antlaşması'na göre 1952 yılında TODAIE (Türkiye Ortadoğu ve Amme İdaresi Enstitüsü'nün kurularak kamu yönetimi alanında araştırma, organizasyon ve metot çalışmalarını yapması, İkincisi de 1960 yılında Başbakanlığa bağlı olarak Devlet Planlama Teşkilatı (DPT)'nın kurulması. Bu iki kurumun kurulmuş olması idarenin yeniden düzenlenmesi çabalarının sistemli bir şekilde yürütülmesi anlamında kurumsallaşma sağlamıştır. Planlı döneme geçildiğinde yapılan başlıca çalışmalar şu şekilde karşımıza çıkmaktadır; Merkezi Hükümet Teşkilatı Araştırma Projesi (MEHTAP), İdarenin Yeniden Düzenlenmesi İlkeler ve Öneriler (IYD) ve Kamu Yönetimi Araştırma Projesi (KAYA).

İdari Reform ve Reorganizasyon Hakkında Ön Rapor: Ocak1961'de Devlet Planlama Teşkilatı kanalıyla Milli Birlik Komitesi'nden yönetimi geliştirme ile ilgili olarak gelen bir istek üzerine TODAİE tarafından yapılmış bir çalışmadır. Raporda idari reform çalışmalarını yürütecek kurumlar olarak, Türkiye ve Ortadoğu Amme İdaresi Enstitüsü, Devlet Planlama Teşkilatı ve Devlet Personel Dairesi belirtilmiş, ayrıca merkezi düzeyde reform çalışmalarını yönlendirecek Başbakan Yardımcısına bağlı bir "İdari Islahat Komitesi” oluşturulması önerilmiştir. Bu ön rapor 1960'tan sonra ve planlı dönemde yapılan çalışmaların başlangıcını oluşturması açısından önem taşımaktadır.

Merkezi Hükümet Teşkilatı Araştırma Projesi (MEHTAP): MEHTAP Raporu, TODAİE ve DPT işbirliği ile 1963 yllında tamamlanıp Başbakanlığa sunulmuş bir çalışmanın ürünüdür (TODAİE, 1963). Yerli uzmanlarca hazırlanan en kapsamlı ve aynı zamanda da en nitelikli metinlerden biridir (Yayman, 2008: 236). Merkezi hükümet tarafından yerine getirilmesi gereken görevlerin yapılmadığı, bu görevleri yerine getirmek için gerekli örgütlenmelere gidilmediği, hizmetlerin halka eşit düzeyde ulaştırılmadığı ifade edilmiştir. Bu sorunların temel nedenleri ise; örgütlenme bozuklukları, kırtasiyecilik, amacından uzaklaştırılmış merkeziyetçilik anlayışı, yönlendirme ve gözetim bozukluğu, 
personel sisteminden kaynaklanan sorunlar olarak sıralanmıştır. Sorunların çözümüne yönelik olarak ise; yönetimi geliştirme politikasının ve hedeflerinin saptanmasına yardım etmek, genel planlar yapmak ve gerekli önlemlerin alınmasını sağlamak üzere Başbakanlıkta merkezi ve genel sorumlu bir birim kurulması, bu merkezi birime ek olarak, bütün bakanlıklarda ve gerek duyulan diğer kuruluşlarda mensubu bulundukları bakanlık ve kurumların yönetimi geliştirme faaliyetlerini yürütmek üzere İdareyi Geliştirme Komitelerinin kurulmasıdır (TODAİE, 1963). MEHTAP Raporunda sorunlar açıkça tespit edilmiş ve ortaya konulmuş olmasına rağmen geliştirilen çözüm önerileri kendinden önceki raporlarda olduğu gibi uygulanma imkânı bulamamıştır.

Ídareyi ve İdari Metotları Yeniden Düzenleme Komisyonu Çalışmaları: Sadece merkezi yönetimin merkez teşkilatını inceleyen MEHTAP çalışmasının kapsam dışı bıraktığı taşra teşkilatı, yerel yönetimler ve KİT'ler deki sorunları ortaya koymak için Devlet Planlama teşkilatı (DPT) tarafından yürütülen tamamlayıcı bir çalışmadır. Bu çalışmayı yapmak üzere DPT bünyesinde 'İdareyi ve İdari Metotları Yeniden Düzenleme Komisyonu' kurulmuştur. Komisyon, yaptığı çalışmaları başbakanlığa sunduktan sonra 1966'da dağılmıştır (Taykut ve İzmirlioğlu, 1975: 3).

İdari Reform Danışma Kurulu Raporu: 12 Mart 1971 muhtırası sonucunda işbaşına gelen hükümet, "idari ve ekonomik yapının modernleştirilmesi” amacına yönelik olarak, 25.05.1971 tarih ve 7/2527Sayılı Bakanlar Kurulu Kararı ile devlet kesiminin yeniden düzenlenmesinin genel yön ve stratejisini tespit etmek üzere bir 'Danışma Kurulu'nun kurulması kararlaştırılmıştır. Kurul, yeni bir araştırma yapmak yerine, yönetimin yeniden düzenlenmesi konusunda daha önce hazırlanan raporlarla diğer çalışmaların bir değerlendirmesini yapmış ve bu değerlendirmeleri içeren rapor, 10.10.1971'de hükümete sunduktan sonra dağılmıştır.

$\mathrm{Bu}$ dönemde yapılan idari reform çalışmalarını uzmanların hazırlamış oldukları bu raporlar üzerinden şöyle bir değerlendirme yapabiliriz; Söz konusu bu raporlarla, idarenin iç işleyişi ile ilgili çok temel sorunlar saptanıp ortaya konulmuş ve bu sorunlara yönelik öneriler de geliştirilmiş olmasına rağmen bu önerileri uygulamaya koyacak kararlı bir siyasi irade mevcut olmamıştır.

\subsection{Kalkınma Planlarında İdari Reform Çalışmaları}

Yerli ve yabancı uzman ve kurum raporlarının yanında, birinci kalkınma planlarından itibaren her kalkınma planında kamu yönetiminin temel sorunlarına ve çözüm yollarına değinildiğini görmek mümkündür. Bunları kısaca şu şekilde özetlemek mümkündür;

Birinci Beş Yıllık Kalkınma Planı'nda (1963-1967) kamu yönetimi reformu, kurumların iç işleyişlerini düzene sokmakla sınırlı kalan dar bir anlayışla ele alınmış; idarenin daha iyi çalışması için, görev, sorumluluk, emir ve yetkilerin açıkça belirlenmesi, kuruluşların bütçe ve malî kontrol usullerinin düzeltilmesi, personel politikasının personelin verimli iş yapabilmesini sağlamak üzere geliştirilmesi gibi kurumsal hedefler ortaya konulmuştur. Bununla birlikte plan, dönemin karma ekonomi anlayışına uygun olarak kamu iktisadi teşebbüslerine (KİT) vurgu yapması ve bu kuruluşların piyasa şartları bağlamında çalışmasının sağlanmasının gerektiğini işaret etmesi açısından önem taşımaktadır. Planın günümüzde de önemli bir tartışma ve sorun alanı olan bölge 
kalkınması ve planlamasına dikkat çekmesi, bölge planlamasına kalkınmanın bölgeler arasında dengeli bir şekilde dağılması ve böylece bölgeler arasındaki dengesizliklerin giderilmesi amaçlarıyla yaklaşması açısından ayrı bir önem taşımaktadır (DPT, 1963; Övgün, 2013: 328).

İkinci Beş Yıllık Kalkınma Planı (1968-1972) ise, yerel yönetimlerin kalkınmada ki önemine ilk kez dikkat çekilmiş olması ve bu kuruluşlar üzerinde idari vesayet yetkisinin azaltılarak bu kuruluşların mali açıdan da desteklenmelerinin ifade edilmiş olması açısından önemlidir (DPT, 1963; Övgün, 2013: 329).

\subsection{Uygulama Boyutunda İdari Reform Çalışmaları}

Cumhuriyetin kuruluş yıllarında, her ne kadar mili burjuvazi yaratmak adına serbest ticaretin desteklenmesi, yabancı sermaye ile ortaklıklara girilmesi gibi liberal hedefler ortaya konulmuşsa da 1929 Dünya Ekonomik krizinin etkisiyle tüm dünyada olduğu gibi Türkiye'de de 1933 yılından itibaren devletçi-plancı politikalar ağırlık kazanmaya başlamıştır. Bu dönemde devlete her alanda görevler verilmiş ve bu anlamda geniş kapsamlı bir kamu örgütlenmesi ekonomik ve toplumsal işleyişin bütününe hâkim olmuştu.

Bu dönemde bakanlık sayısı önceki döneme göre artmıştır. Aynı dönemde Sümerbank (1933), Halk Bank (1933), Etibank (1935), Ereğli Demir Çelik Fabrikası (1935), Maden Tetkik Arama Enstitüsü (1935), Elektrik İşleri İdaresi (1935), Toprak Mahsulleri Ofisi (1938) kurulmuştur. Daha sonraki dönemlerde Türk ekonomisinin lokomotifi olan iktisadi devlet teşekkülleri (1940), Petrol Ofisi (1941), Türkiye Zirai Donatım Kurumu (1944), İller Bankası (1945), Emlak Bankası (1946) kurulmuştur. Aynı dönemde bu iktisadi kuruluşların yanına ulus devletin inşa sürecinde önemli roller üstlenen Halkevleri, Türk Tarih Kurumu, Türk Dil Kurumu, Devlet İstatistik Enstitüsü, İstanbul Üniversitesi, Ankara Hukuk Fakültesi gibi Türk modernleşmesinin temel yapı taşlarını oluşturan örgütler kurulmuş ve Cumhuriyetin kurumsallaşması bağlamında önemli roller üstlenmişlerdir (Yayman, 2005: 74).

$\mathrm{Bu}$ düzenlemelerden başka, yerel yönetimler alanında da önemli reformlar yapılmıştır. Bu anlamda, 3 Nisan 1930 tarihli 1580 sayılı Belediye Kanunu'nun yayımlanması ile birlikte, 53 yıl boyunca yürürlükte kalmış olan "Vilayet" ve "Dersaadet Belediye Kanunları" yürürlükten kaldırılmıştır. Bu kanunla birlikte, o zamana kadar tüzel kişiliğe sahip olmayan belediyeler tüzel kişilik kazanmışlardır (Al, 2005: 108).

$\mathrm{Bu}$ dönemde yerel yönetimler alanındaki başka bir gelişme de 1978 yılında, salt yerel yönetimlerin sorunlarıla yakından ilgilenmek ve gelişmelerine yardımcı olabilmek amacıyla Yerel Yönetimler Bakanlığı'nın kurulmuş olmasıdır. Fakat dönemin yoğun politik tartışmaları içerisinde bu bakanlık gerekli yetki ve sorumluluğu elde edememiştir (Al, 2005: 123).

$\mathrm{Bu}$ dönemde köyler de reform çalışmalarının en önemli odaklarından biri olmuş ve bu alanda çok önemli düzenlemeler yapılmıştır. Bu anlamda öncelikle 1924 yılında 442 sayılı Köy Kanunu kabul edilerek köy yönetimlerinin yapısı ve işleyişine yasal bir nitelik kazandırılmıştır. Ardından, çiftçiyi desteklemek üzere, aşar vergisi kaldırılmış, Ziraat 
Bankası sermayesi ve kredileri arttırılmış, kooperatifleşmeyi sağlamak için önce "İtibar1 Zirai Birlikleri” ve 1929 yılında "Zirai Kredi Kooperatifleri” kanunları çıkarılmıştır ve nihayetinde de 1945 yılında Çiftçiyi Topraklandırma Kanunu çıkarılmıştır. Ancak ne var ki bu uygulama büyük arazi mülklerinin tasfiyesini öngördüğü için güçlü bir muhalefetle karşılaşmış ve uzun süre uygulanmamıştır. 1950 seçimlerinden önce yapılan bir değişiklikle de dağıtılacak arazi hazine ve vakıf arazileri ile sınırlandırılmıştır. Cumhuriyet döneminde köyle ilgili yapılan düzenlemeler açısından 17 Nisan 1940 tarihinde Köy Enstitülerinin açılması ayrı bir önem taşımaktadır. Bu kurumlar, "köy öğretmeni ve köy yararına diğer meslek erbabını” yetiştirerek, köy hayatının ekonomik ve kültürel olarak kalkınmalarında büyük rol oynamışlardır. Ne var ki bu kurumlar da güçlü muhalefetin etkisiyle 1950'den sonra Demokrat Parti iktidarı zamanında tamamen tasfiye edilmiştir.

1963 yılı sonrasında, idari reformların hedefi köylerin kalkınma sorununa odaklanmış ve bu amaçla farklı hükümet dönemlerinde farklı kırsal kalkınma modelleri uygulanmıştır. Bunları; Örnekköy yaklaşımı, Toplum kalkınması yaklaşımı, Köykent yaklaşımı, Merkez-köy yaklaşımı olarak sıralamak mümkündür.

Bunlardan; Örnekköy projesinde, belirli bir özelliği olan köyün, çevresindeki kırsal yerleşmelere örnek olacak nitelikte kalkındırılması; Toplum kalkınması modelinde, kırsal nüfusun kalkınma çabalarına aktif katılımı; Çok yönlü kırsal alan planlamasında Aile planlaması, eğitim, sağlık, sosyal hizmetler planlaması, üretim, pazarlama, tarımda yeni tekniklerin uygulanması, toprağı etkin bir şekilde kullanma esasları, kooperatifçilik alanında yapılan uygulamalarla köyün kendine yeterli birim durumuna getirilmesi ve köykent farklılıklarının giderilmesi; Köy-Kent projesinde, sanayileşmeyi kırsal alana yaymak, kırsal alanda iş olanakları yaratmak, büyük kentlerde sağlıksız kentleşmenin sakıncalarını gidermek ve tarımsal düzeni değiştirmek; Merkez-köy modelinde, tüm köylere ulaştırılamayan sosyal ve kültürel hizmetlerin düşük maliyetle merkez olarak belirlenen köyde toplanması ve çevre köylere sunulması amaçlanmıştır (Çelik, 2005).

1929 y1lı ile başlayan bu uygulamalar ve devlete biçilen müdahaleci model, 1970'lerde yaşanan petrol krizinin sorumlusu olarak gösterilmesine kadar meşruiyetini korumuştur. 1980'lerin sonunda SSCB'nin çöküşü ile birlikte, Sovyet tehdidinin ortadan kalkması, neoliberalizmin yayılmacı politikalarının devreye girmesi ve bu politikaların savunuları doğrultusunda devletin ekonomik ve sosyal alandaki rolünü azaltma girişimleri, devletin müdahaleci uygulamalarının terk edilmesi sonucunu doğurmuştur. Bu yöndeki değişme Türkiye'nin idari reformlarına da yansımıştır. Küresel düzeydeki bu değişikliğin Türkiye'deki izdüşümünü kalkınma planları ve uzman raporları kapsamında sonrasında değerlendirdikten sonra da uygulama boyutunda ele almak yerinde olacaktır.

\section{1980 SONRASI DÖNEMDE REFORM ÇALIŞMALARI}

1980 sonrası dönemde yapılan idari reform çalışmalarında bundan önceki dönemde olduğu gibi uzman raporları ve kalkınma planlarında söz edilen unsurların büyük payı bulunmaktadır. Bununla birlikte, Türkiye-AB ilişkilerinin dönüm noktası olan ve 10-11 Aralık 1999 tarihlerinde Helsinki'de yapılan Helsinki Zirvesi'nde Türkiye'nin adaylığı resmen onaylandıktan sonra bu tarihten itibaren Avrupa Birliği'ne (AB) uyum konusu, Türkiye'nin idari reform serüveninin temel bir amacı haline gelmiştir. Dolayısıyla bu 
tarihten sonra aşağıda da söz edileceği üzere Avrupa Birliği İlerleme Raporları bu sürecin itici güçlerinden biri olmuştur. $\mathrm{Bu}$ nedenle, bundan sonraki gelişmeleri de uzman raporları, kalkınma planları ve AB İlerleme raporları üzerinden değerlendirmek yerinde olacaktır.

\subsection{Uzman Raporlarında İdari Reform Çalışmaları}

İlgi çekici bir şekilde bu dönemden sonra kamu yönetimi konusunda yabancı uzman raporlarına başvurulması pek de fazla olmamıştır. Bu durumun ortaya çıkmasında TODAİE'nin kurulmuş olmasının etkisi büyüktür. Ne var ki yabancı uzman raporlarının yerini 1998 yılından itibaren Avrupa Birliği İlerleme Raporları almıştır. Türkiye'nin AB'ne üyelik için yapmayı taahhüt ettiği yeniden yapılanma girişimleri Türk kamu yönetiminde dönüşümün yönünü belirleyen en büyük unsurlardan biri olmuştur. $\mathrm{Bu}$ dönemde tek kapsamlı araştırma projesi TODAİE tarafından hazırlanan Kamu Yönetimi Araştırma Projesi (KAYA) olmuştur.

Kamu Yönetimi Araştırma Projesi (KAYA), kamu yönetiminin geniş bir bakış açsıyla incelenmesi ve geliştirilmesi için öneriler getirmesi amacı ile DPT'nin isteği üzerine TODAİE tarafından 1988-1990 yılları arasında gerçekleştirilmiş çok geniş kapsamlı bir araştırma projesidir. Kamu Yönetimi Araştırma Projesi’nin amacı, “kamu hizmeti gören merkezi yönetimin merkez ve taşra örgütü ile yerel yönetimleri etkili, süratli, ekonomik, verimli ve nitelikli hizmet görecek bir düzene kavuşturmak; kamu yönetiminin gelişen çağdaş koşullara uyumunu sağlamak; kamu kuruluşlarının amaçlarında, görev, yetki ve sorumluluklarında ve bunların bölünüşünde, örgüt yapılarında, personel sistemlerinde, kaynaklarında ve bu kaynakların kullanış biçimlerinde, yöntemlerinde, mevzuatında, haberleşme ve halkla ilişkiler sistemlerinde var olan aksaklıkları, bozuklukları ve eksiklikleri saptamak ve bu konularda yapılması gerekenleri incelemek ve önermek" olarak belirlenmiştir (TODAİE, 1991).

KAYA projesi, merkezi yönetimi oluşturan genel ve katma bütçeli kuruluşlarla, bunların taşra örgütleri, yerel yönetimler ve öteki kamu kurumlarını da içeren oldukça geniş kapsamlı bir çalışmadır. KAYA' da merkezi yönetim, taşra birimleri ve yerel yönetimlerin bir bütünlük içinde bir arada ele alınması hem yerel yönetimlerin kendi aralarında hem de merkezle ve merkezi yönetimin taşra birimleri arasından ilişki kurması açılarından daha önceki araştırmalara göre büyük bir üstünlük taşımaktadır (Geray, 1993: $10)$.

\subsection{Kalkınma Planlarında İdari Reform Çalışmaları}

Dördüncü Beş Yıllık Kalkınma Planı'nda (1979-1983) o güne kadar yürürlüğe konan üç planda gerçekleştirilmesi istenen çalışmaların istenilen düzeye ulaşamadığ 1 belirtilerek bu durumun doğmasına neden olan sorunları, "Yeniden düzenleme tekniklerinin Kamu Kuruluşlarınca yeterince bilinmemesi, kamu yöneticilerinin buna gereken önemi vermemeleri ve yeniden düzenleme çalışmalarında temel politika ve ilkeleri saptayacak, kuruluşlara yol gösterecek, aralarında eşgüdüm ve işbirliği sağlayacak bir merkezi organın oluşturulamayışı” olarak sıralamıştır. Plan'da yönetimin, çağdaş toplumsal ve iktisadi yapıya uydurulması tekrarlanmakta, Devlet Personel Dairesinin "Merkezi Kamu 
Yönetimini Geliştirme Birimi” olacak şekilde yeniden düzenleneceği ve yeniden yapılanma çalışmalarının DPT sorumluluğunda olacağı belirtilmektedir (DPT, 1979). Ancak bu hedefler gerçekleştirilememiştir.

Beşinci Beş Yıllık Kalkınma Planı'nda (1985-1989) ilk kez "Yönetimin İyileştirilmesi" kavramı kullanılmıştır. Bu amacı gerçekleştirmek için, bürokratik işlemlerin azaltılacağı, kamu yönetimi gelişen toplumsal gereksinimlere ve kalkınma amaçlarına uygun biçimde örgütleneceği, merkezi hükümetin yükünü azaltmak için yerel yönetimlerin güçlendirileceği, vatandaş ile doğrudan teması gerektiren görev ve hizmetlerde yönetimhalk ilişkisinin sistemli bir biçimde yürütülmesine önem verileceği ifade edilmiştir. Planda Bölgesel kalkınma anlayışı kendisinden önceki dört planın anlayışının devamını olarak ve bölgeler, kalkınmada öncelikli yöreler uygulaması yönünde merkezi yönetimin kalkınma çabasına destek olma bağlamında tanımlanmaktadır ( DPT, 1989; Övgün, 2013: 330-331).

1980'li yıllardan sonra, neoliberal söylemler, kapitalizmin içine girdiği krizin sorumlusu olarak devletin müdahaleci uygulamaları ve kurumlarını işaret etmiş ve çözüm olarak da geleneksel kamu yönetiminin eleştirisi üzerine kurulu olan Yeni Kamu İşletmeciliği (YKI) anlayışını kamunun faaliyet gösterdiği pek çok alanda uygulanması olarak sunmuştur. YKİ anlayışı getirdiği ilke ve değerlerle, kamu yönetimini ve kamunun hizmet sunma biçimini önemli ölçüde bir değiş̧ime uğratmıştır. Söz konusu bu değişimin yönünü ise merkezden yerele, yerelden özel sektöre, gönüllü kişi ve kurumlara doğru diye açılamak mümkündür. Değişimin dayandığı temel ilkeler ise, özelleştirme, yerelleştirme, kamusal işlerin görülmesinde piyasa güçlerini öne çıkarma, hukuksal denetimin yerine etkinlik, etkililik verimlilik, performans denetimini tercih etme, yönetimde şeffaflık dayanışma yerine rekabet şeklinde sıralamak mümkündür.

Altıncı Beş Yıllık Kalkınma Planı (1990-1994), tüm dünyada yükselişe geçen neoliberal politikaların söylemlerinin ilk defa açıkça ifade edilmesi açısından önem taşımaktadır. Örneğin, planda, temel ilkeler kısmında yer alan "Büyümenin serbest rekabet şartları içinde gerçekleştirilmesi, iktisadi faaliyetlerde kamunun düzenleyici ve yönlendirici olması, hür teşebbüs ruhunun teşvik edilmesi esastır" ifadesinde hem serbest ticarete hem de düzenleyici devlet rolüne vurgu yapılmaktadır. Politika Esasları kısmında da KİT'lerin modern yönetim anlayışı çerçevesinde rekabet gücünün artırılması suretiyle daha verimli çalışmaları sağlanacağı ve özelleştirilmelerine ilişkin çalışmaların hızlanacağı ifade edilerek hem rekabete hem de özelleştirmeye vurgu yapılmıştır (DPT, 1990).

Yedinci Beş Yıllık Kalkınma Planı (1996-2000), neoliberal politikaların öne sürdüğü YKİ reçetesinin tüm unsurlarını daha açık bir şekilde ortaya koymaktadır. Devletin kamusal hizmetlerle ilgili görevlerinin yeniden değerlendirilmesi, teşkilat yapısının küçültülerek fonksiyonel hale getirilmesi, dengesiz istihdamın düzeltilmesi ve halka dönük bir yönetim anlayışının yerleştirilmesi gereği ve öneminin korunduğu, "devletin asli görevlerini tam olarak yapabilmesi için, özelleştirme yoluyla üretim alanından çekilmesi hızlandırılarak küçülmesi sağlanırken, rekabetçi piyasa koşullarının hakim olmasını sağlamak üzere devletin kural koyma ve konulan kurallara uyulmasını sağlama işlevlerinin ağırlık kazanacağı, rekabet güçlüğü çekilen sektörler öncelikli olmak üzere sanayide yapısal sorunların, bir program dahilinde çözümleneceği, özelleştirmeye hız verileceği, yabancı sermaye girişini hızlandırmak amacıyla bir yandan özelleştirme faaliyetlerine ivme 
kazandırılacağı, performansın ölçülmesine yönelik denetim sistemine geçileceği ve 'Kamu Denetçisi (Ombudsman)Sistemi'nin Türkiye'de de kurulmasının sağlanması gerektiği" ifade edilmiştir (DPT, 1996).

Sekizinci Beş Yıllık Kalkınma Planı'nda (2001-2005) Avrupa Birliği'nin, Türkiye'nin küreselleşme hareketinde önemli referans noktalarından birini oluşturacağı, Türkiye'nin Avrupa Birliği'ne tam üyelik adaylığının onaylandığı Helsinki Zirvesi kararları doğrultusunda, üyelik hedefinin gerçekleştirilmesine yönelik gerekli adımların atılacağı, Plan döneminde Kopenhag kriterlerinin sağlanmasına ve Topluluk Müktesebatı' nın benimsenmesine yönelik önlemlerin alınmasına hız verileceği, Avrupa Birliği’ne üyelik hedefi doğrultusunda, Avrupa Birliği'nin müktesebatının üstlenilmesi ve uygulanmasına yönelik yönetsel kapasitenin geliştirileceği ifade edilmiştir (DPT, 2001). Buradan da anlaşılmaktadır ki, özellikle 2000 yılı sonrası yapılan idari reform çalışmalarının temel yönlendiricilerinden biri de $\mathrm{AB}$ olacaktır.

Dokuzuncu Beş Yıllık Kalkınma Planı'nda (2007-2013) “devletin ticari mal ve hizmet üretiminden çekilerek, politika oluşturma, düzenleme ve denetleme işlevlerinin güçlendirilmesinin esas olacağı, hizmetlerin vatandaşa en yakın birimlerce verilmesinin esas alınacağı, $\mathrm{AB}$ müktesebatına ilişkin müzakerelerin sonuçlandırılarak katılım sürecinin tamamlanmasının amaçlandığı, katılım sürecinin ve üyelik sonrası koşulların gerektirdiği idari yapılanmaya gidileceği, bölgesel gelişme ve yerel kalkınma uygulamalarında yerindelik ilkesinin esas alınacağı, kalkınmaya ilişkin kilit paydaşlar arasında ortaklık kültürü oluşturulacağı, $\mathrm{AB}$ kırsal kalkınma politikalarına uyum için gerekli kurumsal çerçevenin oluşturulacağı, kırsal kalkınma fonlarının yönetimine ve etkin kullanımına iliş̧in idari kapasitenin geliştirileceğì" ifade edilmiştir (DPT, 2007).

Kalkınma planları konusunda bir değerlendirme yapacak olursak öncelikle, bu planları planlı dönem öncesi, planlı dönem sonrası diye ayırmak gerekir. Planlı dönem öncesi, hatta bu dönemin ilk planlarında idari reform kavramının oldukça dar kapsamlı, sadece örgüt içi işleyişle ilgilenen, kamu yönetimini içinde bulunduğu sistemden soyutlayan bir yaklaşım sergilendiği görülmektedir. Nitekim, Ar'ın bu dönem kalkınma planları için tespiti bizce yerinde bir değerlendirmedir. Ar (1983), bu dönem kalkınma planlarının, kamu yönetiminin etkin ve verimli çalışabilmesi için insan kaynakları, örgüt ve materyal sistemlerinde işlemlerin basitleştirilmesi konularında ilkeler ve öneriler getirildiğini bu ilke ve önerilerin gerçekleştirilemediğini ifade etmektedir.

Övgün'ün (2013) belirlemesine göre, her planda kamu yönetimi reformunun bir gereklilik olarak bahsedildiği ve bu bahiste de birtakım ortak amaçların saptandığı gözlemlenmekle birlikte her plan bir önceki dönemin eleştirilmesine dayandığı için kalkınma planları arasında kamu yönetimi reformu açısından bir süreklilikten bahsetmek mümkün görünmemektedir. Bizce bu saptama, Yedinci Beş Yıllık Kalkınma planından sonraki gelişmeler için pek geçerli değildir. Nitekim yukarıda da bahsedildiği üzere, liberal söylemler ilk defa alıncı Kalkınma Planında açıkça ifade edildikten sonra özellikle Yedinci Beş Yıılık Kalkınma Planı sonrasında her seferinde güçlenerek ve daha kararlı bir şekilde ifade edilmiş; hatta ifade edilmekle kalmayıp aşağıdaki anlatımlarda da gözleneceği üzere uygulamada da süreklilik kazanmıştır. Bu kalkınma planlarında sürekli olarak ifade edilen, "yerelleşme, özelleştirme, rekabet, yönetişim, düzenleyici devlet, etkili verimlilik ve performans denetimi, saydamlık, hesap verebilirlik, piyasa 
önceliği, AB müktesabına uyum" vurguları bundan sonra ki idari reformlar da esas alınacak olan eksenler olarak kronikleşmiş gibi görünmektedir.

\section{3. $\quad$ AB İlerleme Raporlarında İdari Reformların Değerlendirilmesi}

Avrupa Birliği ilerleme raporları, Avrupa Birliği Komisyonunun, aday ülkelerin 'Kopenhag Kriterlerini' karşılamak açısından, yasama, yürütme yargı, sivil toplum, eğitim, ekonomi, hak ve özgürlükler gibi alanlar açısından yapmış oldukları çalışmaları birlik standartlarına uyum açısından düzenli olarak izledikleri ve değerlendirdikleri yıllık raporlardır. Türkiye için bir süre "Düzelme Raporu" adı altında çıkan bu raporlar, kamu yönetim sistemini de geniş kapsamlı olarak analiz etmektedir

Bu raporlardan, 1998 Düzelme Raporu'nda Türk kamu yönetimine hâkim olan "yolsuzluk, kayırma ve nüfuz kullanma" durumlarına dikkat çekilmiş (AB Bakanlığ1, 1998); 1999 Yılı Düzelme Raporu'nda "şeffaflık" vurgusu ön plana çıkmış (AB Bakanlığı, 1999); 2000 Düzelme Raporu'nda, yerel yönetimlerde âdem-i merkeziyetçi”" uygulamaların yapılması gerektiği ifade edilmiş (AB Bakanlığı, 2000); 2001, 2002, 2003 ve 2004 yıllarındaki Düzelme Raporlarında "yolsuzluk ve verimsizlik" sorunları tekrar ön plana çıkarılmıştır (AB Bakanlığı, 2001, 2002, 2003, 2004). 2005 İlerleme Raporu'nda "ombudsmanlık" kurumunun kurulması gerektiği belirtilmiş (AB Bakanlığı, 2005); bu gereklilik, 2006 ve 2007 İlerleme Raporlarında da tekrarlanmıştır (AB Bakanlığı, 2006, 2007). 2008 İlerleme Raporu'nda, şeffaflık vurgusu tekrar öne çıkarılmış ve bu anlamda Kamu Mali Yönetimi ve Kontrol Kanunu'nun tamamen uygulamaya girmesini temin etmek için çaba gösterilmesi istenmiştir (AB Bakanlığı, 2008).

2009, 2010 ve 2011 yılları İlerleme Raporlarında "şeffaflık, hesap verebilirlik, liyakat vurguları" öne çıkarılmış, bu ilkelere "e-hizmet ve bilgi sunumunun geliştirilmesi, kamu kurumlarında iç denetim sisteminin kurulması" beklentileri de eklenmiştir (AB Bakanlığ1, 2009,2010,2011). 2012 İlerleme Raporu'nda, “Ombudsmanlık Kurumu'nun” kurulması memnuniyetle karşılanmakta (AB Bakanlığ 1,$2012 ; 2013$ İlerleme Raporu'nda kamu yönetimi reformunun geliştirilmesinde önemli bir unsur olabilecek "performans denetimlerinin" yapılmadığı öne sürülmekte (AB Bakanlığı, 2013); 2014 İlerleme Raporu'nda kamu yönetimindeki "siyasileşme" riskinden söz edilmekte (AB Bakanlığg, 2014); 2015 İlerleme Raporu'nda da bu risk tekrarlanmaktadır (AB Bakanlığı, 2015).

Özellikle, 2005 yılından sonra, Avrupa Birliği ilerleme raporlarındaki öneri ve eleştiriler doğrultusunda, Türkiye'de kamu yönetiminde hem merkezi hem de yerel düzeyde, hızlı bir yeniden yapılanma sürecine girilmiştir. $\mathrm{Bu}$ sürecin nasıl ilerlediği aşağıda açıklanmıştır.

\subsection{Dönem İdari Reform Çalışmaları}

1980'li yıllardan sonra küreselleşme süreci ile birlikte yükselişe geçen neoliberal politikalar pek çok alanın yanında devletin görev ve sorumlulukları da köklü bir değişime uğratmıştır “Herkesi ve her şeyi derinden etkileyen bu süreçte, 50'li ve 60'lı yıllarda refah ve sosyal adalet adına müdahaleci devletler popülerleşirken, 70'li yıllarda şartlar farklılaşmış ve devletin küçültülmesi fikri güç kazanmıştır” (Canpolat ve Cangir, 2010: 
26). "Bu dönüşüm sürecinde, yirminci yüzyılın büyük bir bölümüne hâkim olan Geleneksel Kamu Yönetimi modeli ağırlıklı olarak 1980'lerin ikinci yarısından itibaren, daha esnek ve piyasa tabanlı Yeni Kamu Yönetimi modeline dönüşmeye başlamıştır" (Gökçe ve Erol, 2008: 177).

Bu değişim sürecinde kamusal işlerin görülmesinde özel sektör, gönüllü kurum ve kuruluşlar ve yerel yönetimler artan oranda söz sahibi olmaya başlarken, eşitlik, kamusal yarar, hukukun üstünlüğ̈̈, dayanışma gibi kamusal değerler yerlerini "ekonomiklik, verimlilik, kullanan öder, kar, performans, sözleşmecilik, rekabet" gibi işletme değerlerine bırakmaya başlamıştır.

Yeni Kamu Yönetimi anlayışından etkilenerek bu dönemde devletin daha minimal bir yapıya kavuşturulması, halka daha çok söz hakkının verilmesi, devletin daha şeffaf ve hesap verebilir bir yapıya kavuşturulması amaçlanmıştır (Özer ve Önen, 2016: 226)

Günümüzde kamu yönetiminin faaliyet alanına giren her yerde yeni kamu yönetimi anlayışının izlerini görmek mümkündür. Özellikle 2002 yılından sonra, kamu mali yönetimi, kamu personel yönetimi, denetim, merkezi yönetim, yerel yönetimler ve diğer ilgili alanlarda YKI' nin temel unsurlarını uygulamaya geçirecek önemli yasal düzenlemeler gerçekleştirilmiştir. Bu bağlamda, 2003 tarihli ve 5018 Sayılı Kamu Mali Yönetimi ve Kontrol Kanunu ile birlikte YKİ anlayışı doğrultusunda analitik bütçe sınıflandırmasına geçilmiş, bütçe kapsamı genişletilmiş, kamu kurum ve kuruluşlarında stratejik yönetim ve performans yönetimi uygulamaları başlatılmış, kamu harcama ve denetim sistemi yeniden yapılandırılmıştır (T.C. Resmî Gazete, 2003b; Lamba, 2014: 138).

Kamusal tüm bilgi ve belgelere ulaşımın sağlanması amacıyla 2003 tarih ve 4982 sayılı Bilgi Edinme Kanunu çıkarılmış (T.C. Resmî Gazete, 2003a), 2004 tarih ve 5176 Sayılı Kamu Görevlileri Etik Kanunu Kurulu ve Bazı Kanunlarda Değişiklik Yapılması Hakkındaki kanun (T.C. Resmî Gazete, 2004c) ile kamu yönetiminde etik standartları oluşturulmuştur.

2004 yılında merkezi yönetimin planlama, programlama ve denetim ile sınırlandırılması ve yerelleşmeye öncelik verilmesini amaçlayan 5227 Sayılı Kamu Yönetiminin Temel İlkeleri ve Yeniden Yapılandırılması Hakkındaki Kanun tasarısı meclis tarafindan oylanmışsa da dönemin Cumhurbaşkanı tarafından yayımlanması uygun bulunmayarak TBMM'ye geri gönderilmiş böylece ilgili tasarı kanunlaşma aşamasını tamamlayamamıştır. Bununla birlikte söz konusu tasarının içeriği bundan sonra kamu yönetiminin her alanına müdahale edecek birbirine bağlantılı kanunlar silsilesi halinde uygulamaya geçirilmiştir.

$\mathrm{Bu}$ anlamda ki önemli düzenlemelerden biri, 22 Şubat 2005 tarihinde kabul edilen 5302 sayılı İl Özel İdaresi Kanunu ile gerçekleştirilmiştir (T.C. Resmî Gazete, 2005b). Adı geçen kanun, il özel idaresinin görev-yetki, organları, teşkilatı, insan kaynakları, mali yapısı ve borçlanması, çalışma yöntemleri ve süreçleri, diğer kurumlarla ilişkileri, denetimi ve yönetime katılma konularını yeniden düzenlenmiş ve önemli sayılabilecek yenilikler getirmiştir (Eryılmaz, 2015:180). Yapılan düzenlemelerle il özel idarelerinin özerklikleri artırılmıştır. Bunu sağlamak için; İl genel meclisi başkanlığın validen alınarak meclisin kendi içinden seçeceği başkana bırakılmış ve gündemi belirleme yetkisi 
meclis başkanına verilmiştir. Diğer yandan valinin il genel meclisi kararları üzerindeki denetimi de hukukilik denetimi ile sınırlandırılmıştır.

Yerel yönetimler alanında yapılan başka bir düzenleme de 75 yıldır yürürlükte olan 1580 Sayılı Belediye Kanunu'nun yerini 3 Temmuz 2005 tarihinde kabul edilen 5393 Sayılı Belediye Kanunu'na bırakmış olmasıdır (T.C. Resmî Gazete, 2005a). Bu kanun kamu yönetiminin yeniden yapılandırılması sürecinde belediye yönetimine, ekonomiklik ve verimliliği sağlama, özerkliği artırma ve yönetime katılım açısından önemli yenilikler getirmiştir. Bunları şöylece sıralayabiliriz (Eryılmaz, 2015: 191);

Öncelikle ekonomiklik ve verimliliği sağlamak için belediyenin kuruluş koşulları yeniden düzenlenmiş ve ölçeği büyütülmüştür. Böylelikle, bir yerde belediye kurulması zorlaştırılmıştır. Bu uygulama ölçek ekonomisinin sağlanması ile ilgilidir. Bu uygulamayı desteklemek üzere 6 Mart 2008 tarihli ve 5747 Sayılı Büyükşehir Belediyesi İçerisinde İlçe Kurulması ve Bazı Kanunlarda Değişiklik Yapılması Hakkında Kanun'la, nüfusu 2000'in altına düşen belde belediyeleri köy statüsüne dönüştürülmüş, bazı bucaklar kaldırılmış, bazı köy ve mahallerin birleştirilmesi yolu ile de 43 yeni ilçe kurulmuştur. Diğer yandan, belediyelerde norm kadroya uygun olarak ve sözleşmeli personel çalıştırma olanağı getirilerek personel politikasında etkinlik ve verimlilik ilkeleri öne çıkarılmıştır. Bunun yanında, kalkınma plan ve programlarına ve bölge planlarına aykırı olmamak şartı ile nüfusu 50 bin ve üzerinde olan belediyelerin stratejik plan ve performans planı hazırlama zorunluluğu getirilmiştir.

Bunların dışında, İdari ve mali özerklik çeşitli mekanizmalarla artırılmıştır. Bu anlamda, belediyelerin yapacağı işler liste halinde tek tek sayılmamış, konu konu belirtilmiştir. Diğer yandan belediyelerin yetkili oldukları alanlar eğitim, sağlık, ekonomi, ticaret gibi pek çok alanı içine olacak şekilde çeşitlendirilmiştir. Böylece belediyelerin yerel hizmetler konusundaki yetkileri artırılmıştır. Belediyelere ve il özel idarelerine merkezi yönetimin vergi gelirlerinden aktarılan kaynaklar da artırılmış ve payların belirlenmesine nüfus yanında sosyo-gelişmişlik düzeyi de eklenmiştir. Bu anlamda başka bir düzenleme de merkezi yönetimin ve valinin belediyeler üzerindeki vesayet yetkilerini kısıtlamak yoluyla belediyeler üzerindeki idari vesayetin zayıflatılmasıdır. Bu anlamda; 5393 sayılı yasa, daha katılımcı ve özerk bir belediye öngörmüştür. Mülki idare amirlerinin meclis kararları üzerindeki iptal etme, yürürlüğünü durdurma, değiştirerek onaylama şeklinde uygulanan katı vesayet şekline son verilmiştir. Başka bir deyişle valinin belediye meclisi kararları üzerindeki denetimi hukukilik denetimi ile sınırlandırılmıştır.

Ayrıca Belediyeler bundan böyle mülki idare amiri onayı olmadan serbestçe borçlanabilecekler, istedikleri makamla doğrudan yazışabileceklerdir. Yeni yasaya göre belediyeler, belediye meclisinin kararına ve İçişleri Bakanlığının iznine bağlı olarak görev alanıyla ilgili konularda faaliyet gösteren uluslararası teşekkül ve organizasyonlara, kurucu üye veya üye olabileceklerdir. Bunun yanında belediyelerin sivil toplum örgütleri ve kamu kurum ve kuruluşlarıyla ortak projeler yapabilmesinin önü de açılmıştır.

Belediye yönetiminde demokrasi ve yönetime katılımın sağlanması amacıyla çeşitli düzenlemeler yapılmıştır. Bu anlamda kanuna göre yılda üç defa olağan olarak toplanan meclise her ayın ilk haftası ayrıca da gerekli olduğu hallerde yılda üç defa da olağanüstü toplanma zorunluluğu getirilerek meclis daha işlevsel ve etkili bir konuma getirilmiştir. 
Bunların dişında, demokrasi ve yönetime katılım açısından yeni kanunun getirdiği iki düzenleme daha vardır. Bunlardan biri Kent Konseyleridir. Kanuna göre, kamu kurumu niteliğindeki meslek kuruluşlarının, sendikaların, noterlerin, varsa üniversitelerin, ilgili sivil toplum örgütlerinin, siyasî partilerin, kamu kurum ve kuruluşlarının ve mahalle muhtarlarının temsilcileri ile diğer ilgililerin katılımıyla oluşan kent konseyi kent yaşamında; kent vizyonunun ve hemşerilik bilincinin geliştirilmesi, kentin hak ve hukukunun korunması, sürdürülebilir kalkınma, çevreye duyarlılık, sosyal yardımlaşma ve dayanışma, saydamlık, hesap sorma ve hesap verme, katılım ve yerinden yönetim ilkelerini hayata geçirmesi beklenmektedir. Ancak, kanunda sadece görüş bildirmekle yetkili kılınmış bu konseylerin kendinden beklenen söz konusu bu beklentileri nasıl gerçekleştireceği de tartışmalıdır.

Bunun gibi tartışmalı olan başka bir düzenleme de mahalle muhtarları ve ildeki kamu kuruluşlarının amirleri ile ildeki kamu kurumu niteliğindeki meslek kuruluşları, üniversiteler, sendikalar ve gündemdeki konularla ilgili sivil toplum örgütlerinin temsilcileri, oy hakkı olmaksızın kendi görev ve faaliyet alanlarına giren konuların görüşüldüğü ihtisas komisyonu toplantılarına katılma ve görüş bildirme imkanının getirilmiş olmasıdır. Ancak kent konseylerinde olduğu gibi bu düzenlemede de sadece görüş bildirmekle sınırlı yetkinin demokrasi ve yönetime katılımı artırmada yeterli olup olmayacağı sorusu akıllları meşgul etmektedir.

Yerel Yönetimler alanında diğer bir düzenleme alanı büyükşehir yönetimleri olmuştur; 1984 yılı 3030 sayılı Büyükşehir belediye kanunu 2004 yılına kadar yürürlükte kalmış ve daha sonra yerini 2004 yıl1 5216 sayılı kanununa bırakmıştır (T.C. Resmî Gazete, 2004a). Sekiz yıllık bir uygulamadan sonra 2012 yılında 6360 sayılı yeni Büyükşehir Belediye Kanunu'nun kabul edilmesiyle 5216 sayılı kanun da yürürlükten kaldırılarak toplam 30 Büyükşehir belediyesi kurulmuştur (T.C. Resmî Gazete, 2012b).

Ancak 12.11.2012 tarihli 6360 tarihli Kanunla Büyükşsehir Kanunu değiştirilmiş ve bu kanunla 13 ilde büyükşehir kurulmuş, daha sonra buna Ordu ilinin de eklenmesiyle toplam büyükşehir sayısı 30'a çıkmıştır. Bu düzenleme ile, büyükşehir belediyesi olan illerde; il özel idaresi, belde belediyeleri, köyler ve bucaklar kaldırılmış ve böylece yerel yönetim birimi olarak sadece büyükşehir belediyesi ve ona bağlı ilçe belediyeleri yer almıştır.

Son yıllarda küreselleşme, AB üyelik sürecinin de etkisiyle bölgesel kalkınmanın öneminin artması ve bölgesel kalkınma anlayışında değişikliğe gidilmesi, Bölgesel Kalkınma Ajanslarının kurulmasını zorunlu kılmıştır. Bölge Kalkınma Ajansları' nın kuruluşu, Türkiye'de de 08.02.2006 tarihinde çıkarılan 5449 sayılı Kalkınma Ajanslarının Kuruluşu, Koordinasyonu ve Görevleri Hakkında Kanun ile gerçekleştirilmiştir. 5449 sayılı kanununda kalkınma ajanslarını oluşturma amacı; kamu kesimi, özel kesim ve sivil toplum kuruluşları arasındaki işbirliğini geliştirmek; kaynakların yerinde ve etkin kullanımını sağlamak ve yerel potansiyeli harekete geçirmek olarak açıklanmıştır (T.C. Resmî Gazete, 2006). Kamu-özel sektör ortaklığı anlayışına uygun, geniş katılımlı, teknik kapasitesi yüksek, etkin bir özel sektör kuruluşu gibi faaliyet gösterecek teşkilat yapıları; işe alma ve ücret ödemede uzmanlığa, performansa dayalı ve başarıya odaklı personel sistemi nedeniyle Bölge Kalkınma Ajansları, "Yeni Kamu Yönetimi (YKY)' nin 
desantralizasyon, rekabet, yönetişim ve yönetsel ve mali özerklik ilkelerini karşılayan kuruluşlar" (Lamba, 2014: 143-144) olmaları bakımından önem taşımaktadır.

Yeniden Yapılanmanın denetim boyutunda ise önemli bir gelişme Kamu Denetçiliği Kurumunun kurulmuş olmasıdır. 2012 tarihli ve 28338 sayılı 6328 sayılı Kamu Denetçiliği Kurumu Kanunu ile ombudsmanlık kurumu oluşturulmuş ve ombudsmana idarenin her türlü eylem ve işlemleri ile tutum ve davranışlarını incelemek, araştırmak ve önerilerde bulunma görevi verilmiştir (T.C. Resmî Gazete, 2012a). Denetim konusunda başka bir düzenleme de yerel yönetimleri ilgilendirmektedir. Buna göre; 2005 tarihli 5302 ve 5393 Sayılı Kanunlarla vali ve belediye başkanına stratejik plan, performans kriterleri ve faaliyet planı hazırlama zorunluluğu getirilmiş, merkezin il özel idareleri ve belediyeler üzerindeki yetkileri azaltılarak bu birimlerin özerklikleri artırılmıştır.

Kamuda reform çabaları son yıllarda merkezi yönetim düzeyinde de kapsamlı bir şekilde devam etmiştir. 03.05.2011 tarihinde çıkarılan 6223 sayılı Kamu Hizmetlerinin Düzenli, Etkin ve Verimli Bir Şekilde Yürütülmesini Sağlamak Üzere Kamu Kurum ve Kuruluşlarının Teşkilat, Görev ve Yetkileri ile Kamu Görevlilerine İlişkin Konularda Yetki Kanunu ile kamu hizmetlerine hız ve işlerlik kazandırmak için devlet bakanlığı uygulamasından vazgeçilerek, devletin üstlendiği tüm faaliyetler için icracı bakanlıklar ile bakan olmayan bakan yardımcılıkları oluşturulmuştur. Merkezi yönetim örgütleri olan bakanlıkların teşkilat yapılarında da YKY ilkelerine uygun düzenlemeler yapıllmıştır.

Düzenlemeler sonrası bakanlıkların teşkilat yapılarının daha fonksiyonel hale getirildiği gibi aynı türden hizmetler de tek çatı altında toplanmıştır. Ayrıca, merkez teşkilatı da hizmet sunmaktan çok politika belirleyen, kontrol ve denetimi sağlayan bir rol üstlenmiş; hizmet sunan kurumlarla denetleyen kurumlar birbirlerinden ayrılmışlardır. Diğer yandan dikey yapılanmadan, daha yatay bir yapılanmaya geçilmesinin yanında, yönetişim anlayışına daha uygun olacak şekilde ilgili kesimlerin katılımına olanak sağlayan merkezi düzeyde kurullar oluşturulmuş, bağlı ve ilgili kuruluşlar da yeniden düzenlenmiştir (Lamba, 2014: 146).

Türkiye'de de bu dönemde kamu personel rejimini özel sektör yönetim anlayışına yaklaştırmaya çalışan bazı düzenlemeler hayata geçirilmiştir. 2003 yılından itibaren kamu kurumlarında sözleşmeli personel istihdamı yaygınlaştırılmıştır. Ayrıca kamuya personel alımları merkezi sınav şartına bağlanmış, ilerleme süreçlerinde sınavın yanında liyakate yönelik bazı ölçütler getirilmiş, performansa dayalı sözleşmeli personel uygulaması başlatılmıştır (Lamba, 2014: 146).

Kamudaki reform çalışmalarının bir diğer bileşeni de, e-Dönüşüm Türkiye Projesi ve eDevlet uygulamalarının hayata geçirilmesidir. Buradaki amaç, vatandaşların iş ve işlemlerini hızlandırmak ve çağdaş devlet anlayışına geçmektir. Bu çerçevede, şimdiye kadar farklı kuruluşlar tarafından yürütülen e- Devlet, e-Türkiye, Kamu-Net ve benzeri çalışmalar birleştirilmiş ve bir eylem planı hazırlanmıştır. Buna göre, e-Dönüşüm Türkiye Projesi kapsamında; vatandaşla devlet arasındaki ilişkiyi kuran Mernis projesi tamamlanarak birçok kamu kurum ve kuruluşunda uygulamaya geçirilmiş, vatandaşlık ve vergi numaraları birleştirilmiştir. Ayrıca 5070 Sayılı Elektronik İmza Kanunu çıkartılmıştır (T.C. Resmî Gazete, 2004b). Bu kanunla, bazı kamu kurumlarının sunduğu çeşitli hizmetler, elektronik ortamda sunulmaya başlanmıştır (Bilgin, 2005: 40). 


\section{REFORM ÇALIŞMALARININ GENEL OLARAK DEĞERLENDİRILMESI}

1980 dönemi öncesinde yapılan idari reform çalışmalarını ve kalkınma planlarını birlikte değerlendirdiğimizde bu dönemde yapılan çalışmaların dar kapsamlı ve daha içe dönük ve durağan olduğunu değerlendirmek mümkündür. Ayrıca bu dönemde, idarenin iç işleyişi ile ilgili çok temel sorunlar saptanıp ortaya konulmuş ve bu sorunlara yönelik öneriler de geliştirilmiş olmasına rağmen bu önerileri uygulamaya koyacak kararlı bir siyasi irade mevcut olmamıştır. 1980 dönemi sonrası reform hareketlerini ise daha kapsamlı, dünyada yaşanan siyasal gelişmelerle daha çok ilişkili; köklü toplumsal, siyasal ve yönetsel sonuçları olan, aynı zamanda da kâğıt üstünde kalmayarak uygulanma imkânı bulmuş çalışmalar olarak görmek mümkündür.

Bununla birlikte Türkiye'deki reform hareketlerinin küresel ölçekte yaşanan, devletin rolündeki ve kamu yönetimindeki değişimlere uygun şekilde planlandığı söylenebilir. Örneğin planlı dönem öncesi, Dorr (1933) tarafından yapılan çalışmada kalkınma için gerekli, hamlelerin devlet eliyle yapılması, özel sektörün desteklenmesi, kaliteli yöneticilerin yetiştirilmesi önerilmişken, özellikle Altıncı Beş Yıllık Plan ve onu izleyen diğer planlarda "özelleştirme, serbest piyasanın desteklenmesi, rekabetin artırılması, devletin küçültülmesi, devletin düzenleyici rolünün güçlendirilmesi” gibi yeni kamu anlayışının unsurlarına giderek daha fazla oranda vurgu yapıldığı görülmektedir.

Ancak gelişmiş ülkelerin yönetsel yapılarında reform süreci önemli ölçüde başarı sağlamış olmasına rağmen, Türk kamu yönetiminde aynı sonucun meydana geldiğini söylemek oldukça güçtür. Bunun nedeni kanımızca, başarılı örneklerden uyarlanan reform unsurlarının arkasında yatan ve onları Weber'in rasyonel işleyen bürokrasiye götüren temel değerlerin içselleştirilmesini sağlayacak toplumsal gelişme aşamasına ulaşılamamış olmasıdır.

Weber'in bürokrasi modeli, toplumda devletten bağımsız bir girişimci sınıfın ortaya çıkması ve bu sınıfın kendi değerlerini siyasal hayata, dolayısıyla bürokrasiye aktarması ile varlık kazanmıştır (Canpolat ve Cangir, 2010: 39). Dolayısıyla bu toplumlarda bürokrasi ikincil bir güç ve türev durumundadır. Oysa ki Mardin'in (1992) belirttiği üzere batıda toplumsal ve içsel dinamikler sonucu ve de belirli bir modernleşme aşamasında gelişen bürokrasiye az gelişmiş ülkelerde modernleşme ve modern devletin inşa görevi yüklenmiştir. Dolayısıyla yasal ve rasyonel ölçütlere göre işleyen bir bürokrasinin gereği olan ilkeler, Batı'daki yeniden yapılanma çalışmalarını taklit eden az gelişmiş ülkeler tarafindan içselleştirilememiştir. Böylesine kuvvetli bir rol verilen bürokrasi toplum üzerinde ağır bir vesayet kontrolüne sahip olmuştur. Bu nedenle Canpolat ve Cangir (2010), Türkiye'de bürokrasinin "kurucu" ve "modernleştirici" misyonuna bağlı olarak sistem üzerindeki hamilik ve vesayet rolünü devam ettirdiği sürece yönetimin batılı anlamda araçsal nitelikte yönetsel bir aygıt olarak algılanamayacağını ifade etmektedirler. Biz ise bu öngörüye şunu eklemeyi uygun görüyoruz; İçinde bulunduğumuz yüzyılda, iletişim ortamının gelişmesine paralel olarak demokratikleşme ve insan hakları talepleri de artmaya başlamıştır. Bu anlamda Kamu Yönetimi alanında da demokrasiye, yönetime katılıma, şeffaflığa daha fazla vurgu yapılarak bu değerler çerçevesinde kurumlaşmaya gidilmektedir. Bu gelişmenin izdüşümü olarak da Türk Kamu Yönetiminde Kamu 
Denetçiliği Kurumu, İnsan Hakları Kurumu, Bilgi Edinme Kanunu, Kent Konseyleri, Etik Kurulu, yerelleşme ve özerliğin artırılması gibi uygulamalarla yansıma bulmuştur. Yukarıda sözünü ettiğimiz bürokrasinin toplum üzerindeki vesayeti devam ettiği sürece, toplum yeni yönetim anlayışının getirdiği demokrasi anlayışını içselleştirecek gelişim aşamasına ulaşamayacaktır. Bu durumda yapılan idari düzenlemeler ne kadar çağdaş olsa da kâğıt üstünde kalacak ve kendisinden beklenen başarıyı sağlayamayacaktır. Özellikle son zamanlarda yapılan idari reformlarla bürokrasinin toplum üzerindeki etkisinin azaltıldığı yönünde bir görünüm vardır. Bu reformlarla bürokrasi ve halk arasındaki mesafe görece olarak kapatılmış, halkın karar alma mekanizmalarına katılmasını sağlayan mekanizmalar oluşturulmuş, kamusal işler konusunda bilgi sahibi olma hakkı sağlanmış, bürokratik işler sadeleştirilmiş ve azaltılmış gibi görünmektedir. Ancak tüm bu çalışmaların demokrasi yönünde izdüşüm yapması için hem toplum üzerindeki hem de bürokrasi üzerindeki politik vesayetin de ortadan kalkması gerekmektedir. Sözgelimi, bürokratik atamalarda, yükselmelerde ya da yargı kararlarının verilmesinde siyasal etkilerin uzak tutulması, düşünce ve ifade özgürlüklerinin geliştirilmesi, çoğunlukçu değil, çoğulcu demokrasinin tesis edilmesi, karar alma mekanizmalarında her sınıfın temsil edilmesi, toplumsal isteklerin siyasal güce iletilme yollarının çeşitlendirilmesi, çatışan çıkarların demokratik yollardan ifade edilmesinin sağlanması, sadece bürokraside değil, politik alanda da şeffaflığın sağlanması bu tür vesayetin önüne geçebilir ve toplumu rasyonel işleyen bürokrasiye hazırlayabilir. Bürokrasiyi araç edinmiş ve toplum üzerinde, vesayeti altındaki bürokratik aygıt ile hakimiyet kuran politik güç hem idarenin verimli, akılcı bir yönde gelişmesini engelleyecek hem de toplumun demokrasiyi içselleştirmesi yönünde gelişim göstermesini önlemiş olacaktır.

\section{SONUÇ}

1980’li yıllardan sonra hızlanan küreselleşme süreci ile birlikte yükselişe geçen neoliberal politikaların hayata geçirilmesiyle ülkelerin siyasal ve yönetsel yapılarında büyük dönüşümler yaşanmaya başlanmıştır. Bu gelişmenin etkileri Türk kamu yönetiminde de görülmektedir. Kamu hizmetlerinde neoliberal yeniden yapılandırma süreçleri 1980'lerden itibaren Türkiye'de etkisini göstermeye başlamıştır. Türk Kamu Yönetiminde bu çizgide dönüştürmeye yönelik en ciddi adımlar 2000'li yılların başından itibaren atılmaya başlanmıştır.

Bu çalışmada Türkiye'de yapılan idari reform çalışmaları tarihsel olarak dönemlere ayrıldıktan sonra 2000 yılı sonrası yeniden yapılanma çalışmaları irdelenmiş ve son aşamada da bu çalışmaların başarısı ve geleceği hakkında bir değerlendirme yapılmıştır. Çalışma sonunda Türkiye'de Cumhuriyet tarihinde yapılan idari düzenlemelerin 1980'li yıllara kadar dar kapsamlı ve daha çok örgütsel sorunları kapsayan kapalı bir anlayış hakimken, 1980'li yıllardan sonra daha kapsayıcı ve köklü değişimleri içerdiği belirlenmiştir. Diğer yandan, Türkiye'de idari reform hareketlerinin dünyada yaşanan ekonomik siyasal ve sosyal dönüşümlerin neden olduğu devletin rolündeki değişimlere paralel olarak planlandığı, ancak son döneme kadar bu hareketlerin çoğunun düzenleme aşamasında kaldığı sonucuna varılmıştır. Belirlememize göre özellikle 2000 yılı sonrası bu hareketlerin uygulama olarak da varlık kazanmasına rağmen, toplum üzerindeki hem bürokratik vesayet ve bürokrasi aracılığ ile toplum üzerinde sağlanan politik vesayet 
nedeniyle yeni yönetim anlayışından beklenen demokrasinin gelişmesi yönündeki ilerlemeler pek de kolay olmayacaktır.

Bu çalışmada, Türkiye'de idari reform hareketleri kalkınma planları, uzman raporları ve uygulama açısından dönemsel olarak analiz edilmiştir. Başka çalışmalarda bu konunun hükümet programları ve dönemin siyasal koşulları bağlamında ele alınması faydalı olacaktır. Bu çalışmaya benzer bir araştırma 1980 yılı sonrası idari reform seyrini ortaya koymak üzere $\mathrm{AB}$ İlerleme raporları üzerinden içerik analizi yöntemi ile de gerçekleştirilebilir. Bu çalışmada reform hareketlerinin başarısı ve geleceği hakkında kısa bir değerlendirme yapılmıştır. Bu değerlendirmenin yapılacak başka çalışmalarda daha derin ve ayrıntılı olarak yapılması alana büyük katkı sağlayacaktır.

\section{NOTLAR}

${ }^{1}$ Türkiye'nin ekonomik ve sosyal kalkınmasını hızlandırmak için 30 Eylül 1960 tarihinde 91 sayılı yasa ile kurulan teşkilat 2011 yılında Kalkınma Bakanlığı olarak yeniden organize edilmiştir.

${ }^{2} 1952$ yılında Türkiye Cumhuriyeti ile Birleşmiş Milletler arasında imzalanan teknik yardım anlaşması çerçevesinde kurulan kurum, 1958 yılında çıkarılan 7163 sayılı Kanunla tüzel kişilik ve yönetsel özerklik kazanmıştır (www.todaie.gov.tr).

${ }^{3}$ 17/12/1960 tarihinde 160 sayılı Kanunla Başbakanlığa bağlı olarak Devlet Personel Dairesi adı altında kurulan kurum 1984 yılına gelindiğinde Devlet Personel Başkanlığı adı ile yine Başbakanlığa bağlı olarak yeniden kurulmuştur (http://www.dpb.gov.tr/).

\section{KAYNAKÇA}

AB Bakanlı̆̆ı (1998). Türkiye Düzenli Illerleme Raporu 1998. (Erişim: 30.09.2016), http://www.ab.gov.tr/files/AB_Iliskileri/AdaylikSureci/IlerlemeRaporlari/Turkiye_Il erleme_Rap_1998.pdf

AB Bakanlı̆̆ (1999). Türkiye Düzenli İlerleme Raporu 1999. (Erişim: 30.09.2016), http://www.ab.gov.tr/files/AB_Iliskileri/AdaylikSureci/IlerlemeRaporlari/Turkiye_Il erleme_Rap_1999.pdf

AB Bakanlığı (2000). Türkiye Düzenli Ilerleme Raporu 2000. (Erişim: 30.09.2016), http://www.ab.gov.tr/files/AB_Iliskileri/AdaylikSureci/IlerlemeRaporlari/Turkiye_Il erleme_Rap_2000.pdf

AB Bakanlığı (2001). Türkiye Düzenli Ilerleme Raporu 2001. (Erişim: 30.09.2016), http://www.ab.gov.tr/files/AB_Iliskileri/AdaylikSureci/IlerlemeRaporlari/Turkiye_Il erleme_Rap_2001.pdf

AB Bakanlı̆̆g (2002). Türkiye Düzenli Illerleme Raporu 2002. (Erişim: 30.09.2016), http://www.ab.gov.tr/files/AB_Iliskileri/AdaylikSureci/IlerlemeRaporlari/Turkiye_Il erleme_Rap_2002.pdf 
AB Bakanlığı (2003). Türkiye Düzenli Illerleme Raporu 2003. (Erişim: 30.09.2016), http://www.ab.gov.tr/files/AB_Iliskileri/AdaylikSureci/IlerlemeRaporlari/Turkiye_Il erleme_Rap_2003.pdf

AB Bakanlığı (2004). Türkiye Düzenli Illerleme Raporu 2004. (Erişim: 30.09.2016), http://www.ab.gov.tr/files/AB_Iliskileri/AdaylikSureci/IlerlemeRaporlari/Turkiye_Il erleme_Rap_2004.pdf

AB Bakanlığı (2005). Türkiye Düzenli Illerleme Raporu 2005. (Erişim: 30.09.2016), http://www.ab.gov.tr/files/AB_Iliskileri/AdaylikSureci/IlerlemeRaporlari/Turkiye_Il erleme_Rap_2005.pdf

AB Bakanlığı (2006). Türkiye Düzenli Illerleme Raporu 2006. (Erişim: 30.09.2016), http://www.ab.gov.tr/files/AB_Iliskileri/AdaylikSureci/IlerlemeRaporlari/Turkiye_Il erleme_Rap_2006.pdf

AB Bakanlığı (2007). Türkiye Düzenli Illerleme Raporu 2007. (Erişim: 30.09.2016), http://www.abgs.gov.tr/files/AB_Iliskileri/AdaylikSureci/IlerlemeRaporlari/turkiye_ ilerleme_rap_2007.pdf

AB Bakanlığı (2008). Türkiye Düzenli Illerleme Raporu 2008. (Erişim: 30.09.2016), http://www.abgs.gov.tr/files/AB_Iliskileri/AdaylikSureci/IlerlemeRaporlari/turkiye_ ilerleme_rap_2008.pdf

AB Bakanlığı (2009). Türkiye Düzenli Illerleme Raporu 2009. (Erişim: 30.09.2016), http://www.abgs.gov.tr/files/AB_Iliskileri/AdaylikSureci/IlerlemeRaporlari/turkiye_ ilerleme_rap_2009.pdf

AB Bakanlığı (2010). Türkiye Düzenli Illerleme Raporu 2010. (Erişim: 30.09.2016), http://www.ab.gov.tr/files/AB_Iliskileri/AdaylikSureci/IlerlemeRaporlari/turkiye_ile rleme_rap_2010.pdf

AB Bakanlığı (2011). Türkiye Düzenli Illerleme Raporu 2011. (Erişim: 30.09.2016), http://www.ab.gov.tr/files/AB_Iliskileri/AdaylikSureci/IlerlemeRaporlari/2011_ilerl eme_raporu_tr.pdf

AB Bakanlığı (2012). Türkiye Düzenli Illerleme Raporu 2012. (Erişim: 30.09.2016), http://www.ab.gov.tr/files/AB_Iliskileri/AdaylikSureci/IlerlemeRaporlari/2012_ilerl eme_raporu_tr.pdf

AB Bakanlığı (2013). Türkiye Düzenli Ilerleme Raporu 2013. (Erişim: 30.09.2016), http://www.ab.gov.tr/files/AB_Iliskileri/AdaylikSureci/IlerlemeRaporlari/2013_ilerl eme_raporu_tr.pdf

AB Bakanlığı (2014). Türkiye Düzenli Ilerleme Raporu 2014. (Erişim: 30.09.2016), http://www.ab.gov.tr/files/ilerlemeRaporlariTR/2014_ilerleme_raporu_tr.pdf

AB Bakanlığı (2015). Türkiye Düzenli Illerleme Raporu 2015. (Erişim: 30.09.2016), http://www.ab.gov.tr/files/000files/2015/11/2015_turkiye_raporu.pdf

Al, H. (2005). Cumhuriyet Dönemi Belediyeciliğinin Tarihsel Gelişimi. (der. Vecdi Akyüz), İslam Geleneğinden Günümüze Şehir Hayatı ve Yerel Yönetimler 2, İstanbul, 105-144. 
Ar, A. F. (1983). Türkiye ve Amerika Birleşik Devletleri’nde Yapılan Bazı İdari Reform Çalışmaları. Amme İdaresi Dergisi, 16 (3), 65-88.

Berkman, A. Ü. (1982). Planlı Dönemde İdari Reform Anlayışı ve Uygulanması: İdari Reformun 'Yönetilmesi' Açısından Bir Değerlendirme. Orta Doğu Teknik Üniversitesi Gelişme Dergisi, (özel say1), 207-225.

Bilgin, H. M. (2005). Kamu Yönetiminde Yeniden Yapılanma Tartışmaları. Rekabet Kurumu Perşembe Konferansları, 17 Mart 2005, cilt 20, 27-67, Ankara.

Bozkurt, Ö., Sezen, S., \& Ergun, T. (1998). Kamu Yönetimi Sözlüğ̈̈. Ankara: TODAİE

Canpolat, H., \& Cangir, M. (2010). Değişen Dünyada Kamu Yönetiminin Geleceği ve Türkiye'nin Reform Gündemi: Türkiye'nin Daha Fazla Demokratikleşmesi. Türk Idare Dergisi, (466), 25-46.

Coşkun, B., \& Nohutçu, A. (2005). Türkiye'de Kamu Yönetiminde Yeniden Yapılanma: Kuramsal-Tarihsel Perspektif, Genel Değerlendirme ve Saptamalar. (ed. Ahmet Nohutçu \& Asım Balcı). Bilgi Çă̆ında Türk Kamu Yönetiminin Yeniden Yapılandırlmast-I, İstanbul: Beta Basım Yayım, 1-36.

Çelik, Z. (2005). Planlı Dönemde Türkiye'deki Kırsal Kalkınma Politika ve Uygulamaları Üzerine Bir Değerlendirme. Planlama, (2), 61-71.

Çiftçi, S., \& Çürük, L. (2011). Kamu Yönetiminde Paradigma Değişimi Çerçevesinde Reformlar: İngiltere Örneği. Bartın Üniversitesi İktisadi ve İdari Bilimler Fakültesi Dergisi, 2(4), 25-47.

Çiner, C.U. (2010). Devlet Reformunda Yerelleşme ve Bölgeselleşme: Türkiye’ye Karşılaştırmalı Bir Bakış. Doktora Tezi, Ankara: Ankara Üniversitesi.

DPT (1963). Birinci Beş Yıllık Kalkınma Planı (1963-1967). Ankara: Devlet Planlama Teşkilatı. (Erişim: 30.09.2016), http://www.kalkinma.gov.tr/Lists/Kalknma\%20Planlar/Attachments/9/plan1.pdf

DPT (1968). İkinci Beş Yıllık Kalkınma Planı (1968-1972). Ankara: Devlet Planlama Teşkilatı. (Erişim: 30.09.2016), http://www.kalkinma.gov.tr/Lists/Kalknma\%20Planlar/Attachments/8/plan2.pdf

DPT (1973). Üçüncü Beş Yıllık Kalkınma Planı (1973-1977). Ankara: Devlet Planlama Teşkilatı.

(Erişim: 30.09.2016), http://www.kalkinma.gov.tr/Lists/Kalknma\%20Planlar/Attachments/7/plan3.pdf

DPT (1979). Dördüncü Beş Yıllık Kalkınma Planı (1979-1983). Ankara: Devlet Planlama Teşkilat. (Erişim: 30.09.2016), http://www.kalkinma.gov.tr/Lists/Kalknma\%20Planlar/Attachments/6/plan4.pdf

DPT (1989). Beşinci Beş Yıllık Kalkınma Planı (1985-1989). Ankara: Devlet Planlama Teşkilati. (Erişim: 30.09.2016), http://www.kalkinma.gov.tr/Lists/Kalknma\%20Planlar/Attachments/5/plan5.pdf 
DPT (1990). Altıncı Beş Yıllık Kalkınma Planı (1990-1994). Ankara: Devlet Planlama Teşkilatı.

(Erişim: 30.09.2016) http://www.kalkinma.gov.tr/Lists/Kalknma\%20Planlar/Attachments/4/plan6.pdf

DPT (1996). Yedinci Beş Yıllık Kalkınma Planı (1996-2000). Ankara: Devlet Planlama Teşkilatı. (Erişim: 30.09.2016), http://www.kalkinma.gov.tr/Lists/Kalknma\%20Planlar/Attachments/3/plan7.pdf

DPT (2001). Sekizinci Beş Yıllık Kalkınma Planı (2001-2005). Ankara: Devlet Planlama Teşkilatı. (Erişim: 30.09.2016), http://www.kalkinma.gov.tr/Lists/Kalknma\%20Planlar/Attachments/2/plan8.pdf

DPT (2007). Dokuzuncu Kalkınma Planı (2007-2013). Ankara: Devlet Planlama Teşkilatı. (Erişim: 30.09.2016), http://www.kalkinma.gov.tr/Lists/Kalknma\%20Planlar/Attachments/1/plan9.pdf

Ergun, T. (1991). Yönetimin Yeniden Düzenlenmesi Gereksinimi ve KAYA Projesi. Amme Idaresi Dergisi, 24(4), 11-23.

Eryılmaz, B. (2015). Kamu Yönetimi. Kocaeli: Umuttepe Yayınları

Geray, C. (1993). KAYA Yazanağı Açısından Yönetimin Taşra Birimlerinin ve Yerel Yönetimlerin Yeniden Düzenlenmesi. Çăgdaş Yerel Yönetimler Dergisi, 2(1), 9-17.

Gow, J. J. (2012). Administrative Reform. (Ed. Savard Cote), Encyclopedic Dictionary of Public Administration. (Erişim: 02.09.2016), http://www.dictionnaire.enap.ca

Gökçe, O., \& Erol T. (2008). Kamu Yönetiminin Dönüşümü ve Dönüşümün Temel Unsurlar1. Sosyal ve Ekonomik Araştırmalar Dergisi, 8(15), 175-200

Güler, B. A. (1996). Yeni Să̆ ve Devletin Değişimi. Ankara: TODAİE.

Kara, B. (2006). Türkiye'de Personel Reformu Çalışmalarının Altyapısı: 1930-1960 Yılları Arasında Yabancı Uzmanların Kamu Yönetimine İlişkin Hazırladıkları Raporlar. Cumhuriyet Üniversitesi IIIBF Dergisi, 30 (2), 149-162.

Karaer, T. (1991). Kalkınma Planları ve İdari Reform. Amme İdaresi Dergisi, 24 (2), 43 65.

Kılıç, R. (2006). İktisadi Düşünce; İktisadi Düşüncenin Gelişimi, İktisadi Düşünce Okullarl, Iktisadi Düşünürler. Ankara: Siyasal Kitabevi

Lamba, M. (2014). Yeni Kamu Yönetimi Perspektifinden Türkiye'de Kamu Yönetimi Reformları: Genel Gerekçeler Üzerinden Bir İnceleme. Suleyman Demirel University The Journal of Faculty of Economics and Administrative Sciences, 19(3), 135-152

Mardin, Ş. (1992). Türk Modernleşmesi. İstanbul: İletişim Yayınları

Övgün, B. (2013). Değişmeyen Kamu Politikası: Kamu Yönetimi Reformu. ,AİBÜ Sosyal Bilimler Enstitüsü Dergisi, 13(2), 325-339.

Özer, M. A., \& Önen, S. M. (2016). 200 Soruda Yönetim/Kamu Yönetimi. Ankara: Gazi Yayınları. 
Sürgit, K. (1972). Türkiye'de İdari Reform, Ankara: TODAİE.

Şaylan, G. (1995). Değişim Küreselleşme ve Devletin Yeni İşlevi. Ankara: İmge Kitabevi.

T.C. Resmî Gazete (2003a). Bilgi Edinme Kапиnu, 25269, R.G. 24/10/2003, KN. 4982, KT. 9/10/2003.

T.C. Resmî Gazete (2003b). Kamu Mali Yönetimi ve Kontrol Kanunu, K.N.5018, K.T. 10/12/2003, R.G.24/12/2003, Say1 :25326

T.C. Resmî Gazete (2004a). Büyükşehir Belediyesi Kanunu, 25531, R.G.23/7/2004, KN. 5216, K.T. 10/7/2004.

T.C. Resmî Gazete (2004b). Elektronik İmza Kanunu, 25355, R.G. 23/1/2004, K.N. 5070, K.T.15/1/2004.

T.C. Resmî Gazete (2004c). Kamu Görevlileri Etik Kurulu Kurulması ve Bazı Kanunlarda Değişiklik Yapılması Hakkında Kanun, K.N. 5176, K.T.25/5/2004, R.G. 8/6/2004, Sayı :25486

T.C. Resmî Gazete (2005a). Belediye Kanunu, 25874, RG. 13/7/2005, KN.5393 KT.3/7/2005.

T.C. Resmî Gazete (2005b). Il Özel İdaresi Kanunu, 25745, R.G. 4/3/2005, KN. 5302, K.T.22/2/2005.

T.C. Resmî Gazete (2006). Kalkınma Ajanslarının Kuruluşu, Koordinasyonu ve Görevleri Hakkında Kanun, 26074, R.G. 8/2/2006, K.N. 5449, K.T. 25/1/2006.

T.C. Resmî Gazete (2012a). Kamu Denetçiliği Kurumu Kanunu, KN. 6328 K.T. 14/6/2012, R.G.29/6/2012, Say1: 28338

T.C. Resmî Gazete (2012b). On Üç Illde Büyükşehir Belediyesi ve Yirmi Altı Illçe Kurulması ile Bazl Kanun ve Kanun Hükmünde Kararnamelerde Değişiklik Yapılmasına Dair Kanun, KN.6360, R.G. 6.12.2012, Sayı:28489

Taykut, R., \& İzmirlioğlu, A. (1975). Planlı Dönemde Kamu Yönetimi Çalışmaları. Yayın No: 1452. Ankara: DPT Yay.

TODAİE (1963). Merkezi Hükümet Teşkilatı Araştırma Projesi Yönetim Kurulu Raporu: Merkezi Hükümet Teşkilatı Kuruluş ve Görevleri (MEHTAP). Ankara: TODAİE Yayınları.

TODAİE (1991). Kamu Yönetimi Araştırması Genel Rapor (KAYA). Yayın No: 238, Ankara: Devlet İstatistik Enstitüsü Matbaası.

Tutum, C. (1994). Kamu Yönetiminde Yeniden Yapılanma. Ankara: TESAV Yayınları.

Yayman, H. (2005). Türkiye’nin İdari Reform Politiği. Doktora Tezi. Ankara: Ankara Üniversitesi

Yayman, H. (2008). Türkiye'nin İdari Reform Tarihi. Ankara: Turhan Kitabevi. 
